UDC: $316.7: 911.3(498=477)$

\section{Camelia BURGHELE}

County History and Art Museum

of Zalau (Romania)

cameliaburghele@yahoo.com

Камелія БУРГЕЛЕ,

Повітовий музей історії та етнографії, Залеу (Румунія)

\section{ANTHROPOLOGY AT HOME: THE COMMUNITY OF ROMANIAN VILLAGES \\ ON THE RIGHT TISA RIVER BANK (ZAKARPATHIA, UKRAINE)}

Ключевые слова: историческая область Марамуреш, румынские села Закарпатья, культура Карпат, этническая и культурная идентичность, идентичность гранищыл.
Бургеле Камелия. Домашняя антропология: сообщество румынских сел на правобережье Тисы (Закарпатье, Украина)

Предлагаемое исследование имеет целью этнографическое описание региона Марамуреш в течение последних лет по всему правобережью Тисы. Статья представляет некоторые особенности истории Марамуреш на севере Тисы. Важно, что историческая область Марамуреш относится к географическому региону, из которого только треть принадлежит Румынии, а остальные две трети принадлежат Украине. Румыноязычное населения здесь всегда относилось к своему происхождению независимо от контекста глобализации. Идентичность румынской общины на границе Украины, на исторической территории Марамуреш, построена на нескольких уровнях частично на основе местных особенностей и традиций, а частично подчинена изменениям и ориентации на глобализацию в связи с культурной ассимиляцией. Эти уровни связаны с моделями поведения и менталитета жителей Марамуреш.
This article presents a few features of Maramures history on the north of Tisa. We have to keep in mind that the "historical Maramures" refers to a geographical space of which only a third belongs to the Romanian state as the other two thirds belong to Ukraine: the Romanian Maramures covers 3300 square kilometers of the 10500 total of the whole Maramures.

It is important to know that this paper is part of a more complex research - Assumption of the cultural identity in the Romanian communities in the Ukraine Maramures (Trans-Carpathia - Ukraine) conservation and/or social cultural dynamics in a multi ethnical context, within the Romanian Academy project "Putting value to cultural identities within global processes", European Social Fund, POSDRU 2007 - 2013.

The Ukrainian official documents (especially the results to the 2001 census) indicate the fact that in the Zakarpathia region in Ukraine 32000 Romanians live within an area called (also) The Northern Maramures - the districts of Rahãu ( Biserica Albã, Apșa de Mijloc, Apșa de Sus, Apșița Veche, Dobric, Plãiuț, Strâmba, Paladi) i Teceu (Slatina, Apșa de Jos, Strâmtura, Teteș, Peri, Podișor, Bescãu, Cãrbunești, Bouțul mare, Bouțul Mic).

Historically speaking, the Ukraine Maramures villages have been recorded in the XIV century and are an example of ethnical and cultural survival, if we consider the fact that several empires and administration have walked upon their territory: the Hungarian Kingdom, The Transilvania Principate,
The Austrian Empire, The Austrian-Hungarian Monarchy, Czechoslovakia and the USSR.

We have approached this matter on two levels by employing the cultural anthropology instruments: Romanian culture - as part of the Carpathian culture and Romanian culture - as a feature of cultural expansion.

This cultural model is sustained by folklore theorist Adrin Fochi who would talk about "Carpathian culture unity" and of the fact that Carpathian culture "has an ancient and unitary ethnical foundation involving millennia of history and huge geographical areas (...) which is a typical way to manifest within the culture of all the people that settled and mingled in that certain area in time"1. Fochi quotes literature which supports - especially with ethno-linguistic proof - a great migration of the "valahi" sheperds along the Northern Carpathians: "a current of Romanian culture existed in the Middle Ages that initiated in Northern Trasylvania and Maramures and set itself on way towards the North on both Carpathian sides, on the Eastern side of the mountain through Silezia to Podhale and on the Western side from Northern Hungary, through Slovakia to Moravia. So it is a migration current from the South to the North; one should also notice the Romanian ("valah") origin of this current".

The "Carpathian culture" issue (maybe even that of "carpathianism") was followed as a recurring theme in anthropology during the last years, as a result to deep Europe-oriented and global-oriented 
processes of culture and economy. Beyond the approaches offered by the theoretical framework of globalization, minority anthropology explains a series of social-cultural phenomena - most of which are present in the Romanian villages of Ukraine by acting out the concept of cultural and national identity and through the dynamics between the majority and the minority group - followed by cultural policies and heritage guarding for each of the parts.

Ion Popescu gave us some very well documented data, regarding the Ukraine areas where ancestors of the Romanians live - "valah" populations. Historian Dumitru Manolache wrote about the "valah" shepherds and Romanian rulers who had already been Slavicised in a "Romanian land" in Galitia in the XVIIIth century. Hasdeu talks about the "bolohi" in Eastern Ukraine; Michailo Lucikai a romantic period historian, contemporary with Petru Maior agrees with his historical precursors who talk about a "nomad valah population" who would "heard their flocks on a area that had not been devastated between the suburbs of Constantinople all the way to the Tracia border, across the Balkan mountains. A very interesting case is offered by the discovery of a "valah" or "voloh" group within the Romanian Trans-Carpathia across the Tisa River in Ukraine.

In this context Carpathian culture becomes a paradigm which defines the cultural european environment. The matrix of customs and traditions (guarded either "in situ" or in the cultural memory of the group) in the villages on the right bank of Tisa are brought together into a solid argument for belonging to a specific mountain culture under the pressure of Ukraine, Russia and Hungary. This culture is in unity with that of the European Cartpathians but even more, it is in perfect sync with the culture built upon the Romanian Carpathians.

Recognition of the identity of these Romanians through guarding certain traditions and customs makes possible not only the "rediscovery of the archetype" needed by the Transarpathian Romanians to guard their unity and cultural continuity but also the development of a complex anthropological research of the area, in order to theoretically and practically argument Carpathian culture.

Direct field observation has led us to see a series of three stages within the construction of a Ukraine Romanians border-identity:

- The first one, which is compulsory and governs the everyday life of Trans-Carpathian Romanians is that of the geo-political space to which they actually belong: a country named Ukraine in which Romanians are Ukraine citizens, they have rights and benefits and they abide to that country's law;

- The second one, an ethnical one, also emotional and cultural is that of the country they belong to according to their nationality: Romania which is seen as a „their space” and of which they were separated by historical chance;

- The third element is that of the historical Maramures - a proximal space of identity legitimacy, cultural and territorial unity and often with some mythical components

From the perspective of contemporary history one can talk about the population across Tisa in North Western Romania as "an important Romanian community" which is dominated by the same features as the Romanian Maramures with which forms a geographical, ethnical and historical unity if not an administrative one. The territory we speak about is conventionally named the "Historical Maramures" by the historians but the Romanians call this area "Little Romania".

The territory under our discussion is conventionally called by the historians "historical Maramures" but the local Romanians call this area "Little Romania". With historical precision but also with an ironic smile Romanian historians note the fact that in 1919, at the Paris Peace Conference it was ruled that this territory become a part of... Czechoslovakia. This fact has never been understood by us as Romanians have nothing whatsoever in common with the Czechs or the Slovaks («it was annexed to Czechoslovakia without any prior consultation of the people's will within this area»). In 1939, Horthyst Hungary annexed this territory and after World War II, as result to an agreement between Stalin and Prague the area becomes component of the USSR, or rather of the Ukraine Socialist Soviet Republic. Even though along history the local borders have been changed as often as the political regimes the community here guarded its unity, thought tradition and mother tongue.

While surrounded by strong Ukrainian communities representing majority, Romanian villages in the Ukraine Trans-Carpatia have activated along history some very well defined mechanisms to guard their cultural identity which have to be activated today as well.

The Romanian villages of Trans-Carpathia are radically different from the rest of the (Ukrainian, Slovak, Hungarian) villages because of the villagers' wellbeing. This is a vital argument in outlining an identity profile for the Romanians, obtained by comparison to the other ethnicities within the same geographical area and social status. Based onto this remark we are looking to accomplish a collective study on dynamic identity / alterity mechanisms: how do Romanians perceive themselves concerning their social and material status and how the other ethnicities perceive them - of which the majority of Ukrainians are the most important, and weather this gives them a special status.

Returning to the mechanisms of identity and alterity construction and targeting especially sequences that belong to the local culture and civilization it is obvious that socio-culturally the TransCarpathian Romanians build their well-defined 
identity within the context of ever tougher context of a Ukrainian and/or Russian globalization while focusing on some exponential, clear historical cultural marks:

- The ruler Bogdan who founded Moldavia starting from the Carpathians across Tisa

- Mucacevo, the spot where the first orthodox diocese in Transilvania was born

- The Peri monastery where the first Romanian holy Scripture was edited

- Academy professor Ioan Mihalyi de $\mathrm{Ap}^{\circ} \mathrm{a}$, the editor of "Diplome Maramure ene"

- Academy professor and folklore researcher Mihai Pop

Our field research - initiated chiefly for an ethnographical description of the area - developed over the last years across Tisa convinced us of the effort of the Romanians here to guard their ethnical and cultural identity. The Romanians here always relate to their Romanian origins regardless of this globalization context. They feel Romanian Maramures inhabitants and they keep trying to maintain this image through the instruments they have: visits to their brethren in the Romanian Maramures, cultural exchange, Romanian language schools, restoration of Orthodox churches or Catholic, collecting and preserving old objects specific to Romanian traditional villages and even opening small museums when possible, printing periodicals in Romanian and, above all, willingness to teach children the Romanian language (which they talk daily in the family).

Past these observations, Romanians here have traditions, customs, culture, costumes, churches, construction, anthroponyms and especially a common language with the inhabitants of Maramures in Romania, Transcarpathia Romanians have developed a very strong national consciousness. We consider impressive they call themselves "Little Romania" and relate to "Big Romania". This not only to express their pride to be as Romanians as the Romanians in Romania, but also to access the culture generated by assuming well-defined attitudes, a unique history based on the existence of a desire perpetuated from generation to generation to belong to the "Big Romania".

In the field research developed in the Romanian villages right of Tisa (Transcarpathian Ukraine), to define group identity and border identity we investigated several aspects. The first one was language, where we reasearched the level of understanding, and usage of the mother tongue, the contexts of using the language, use of other languages (mainly Ukrainian and Russian). On a ethno-linguistic level we also studied the way they feel about other language speakers or the role played by language in choosing a partner - detection of features to substantiate alterity (the way they look at "others": do they assimilate them, reject them or accept them). Another aspect was that of religion as an effect to guarding an identity but also to relate to other religions as an element to generate alterity.

From an economic perspective we discussed about property and inheritance, but we also tackled an imagology side: how Romanians relate, from an economic perspective (inherited or acquired wealth and attitude towards work) to other ethnicities.

As for the other major aspect, the social one, interest was aroused by alterity still: the ethnocultural references that generate Romanian ethnic demarcation from the "others" and the relevant attributes of each ethnic group imagined while interacting with Romanians. Social contact was also important to catalogue practices and its circumstances.

Another aspect that revealed very interesting information in outlining border identity was the magical-mythical ritual level: magic and ritual practices, interference with the religion, the occurrence of changes in the structure of these rituals and possible alterations of the rituals, customary practices centered on different events or holidays.

The Romanian ethnic group at the right of Tisa consists basically of a few social networks built on three levels: kinship, neighborhood and local community. Within the category of parenting networks were observed of the parental territory, with focus on endo-and exogamous marriage, parenting network activation contexts (with an emphasis on holidays and customs of family life) and the composition and structure of groups / families.

Neighborhoods were measured in terms of group cohesion and group ethnic proximity but also with the Romanians in Romania, especially in the area of Maramures. The local community showed great interest in: social structure, internal cohesion, the importance of the linguistic elements and religious and community issues related to legal and administrative arrangements (relations with the authorities), political and civic, economic (especially migration on the labor market).

Often the configuration of the identity territory led to the construction of a mentality map, which is a common tool for social geography.

Within the researched area, the spoken languages are Romanian, Ukrainian and Russian. Romanian was taught at home, as within the family Romanian is spoken. Language surveys applied to a large number of subjects shows that Romanians here know to read and write in Romanian and understand it perfectly. They read the Bible in Romanian, as well as newspapers and radio and TV is watched in Romanian (broadcasted by satellite). Romanian is also used locally for matters concerning the authorities.

Linguistically, one can notice an archaic Romanian, specific to the XIX th century with several words taken from Ukrainian, Russian or Hungarian.

A primary and secondary learning system works well in the Romanians villages and surprisingly, even though some of these are spread over a large 
area or are very small young and highly qualified personnel predominates. Virtually in every Romanian village at least one Romanian language school is present.

There are more than 100 confessions in the Romanian villages and in all of these the service is performed in Romanian. However the fact that should concern us is the fact that after the Ukrainian church split apart many of the Christians left their old religion and became Jehovah's witnesses.

Most of the people we interviewed were Jehovah's Witnesses but also paro-Slavic orthodox, Greek-catholic and/or Roman-catholic.

From the point of view of the historical traditions and of the cultural heritage in each village there is a Christian church, orthodox and/or Greekcatholic. The orthodox churches or Greek Catholic ones are served by priests who perform in Romanian. Most have studied in Romania but also in Kyiv and Moscow. All churches subordinate to the Hust Diocese but also to the Russian Patriarch in Moscow.

The old cemeteries are in a bad condition with graves without cross or with inscriptions which time has erased. The modern cemeteries have a more awkward look with black marble which have the dead ones' pictures engraved with a special process, imported from the West.

In these communities, endogamous marriages predominate but mixed marriages also exist though relatively scarce. Close relatives marry to one another, frequently 3 and 4 degree cousins but sometimes even 2 degree or even 1 st degree cousins. The age for marriage is a low one: 15-16 years in girls and 18-20 in boys. These marriages are carried out with a permit from the town hall and so they become legal.

Similarly to the other ethnographical area in Romania, across Tisa agriculture and animal breeding were of interest but also other secondary occupations like backyard ones like beekeeping and some traditional crafting.

Due to alpine pastures which allowed a very good management of the corrals for the summer with loads of food for the sheep, sheep herding has always been privileged amongst the Maramures local occupations. Prestigious ethnographers like Romulus Vuia nd Mihai Dancus thouroughly analyzed sheep herding on Maramures while describing it with freat detail with all its economic aspects and those linked to society, culture, ritual, according to a well set annual cycle which had been transmitted from generation to generation.

Salt mining in salt mines on the left and right side of Tisa occupied a very important spot within the local occupations. The references to the Slatina salt mines are very numerous with our informants. In fact, archaeological proof shows how salt was mined as early as prehistory and medieval documents describe a sustained mining activity dotted by many revolts by the workers proof that this work was hard and badly paid. On top of that we have also some adjacent information which describes the importance of the salt mines: "Many rafts were ridden on Tisa for salt transportation. This happened when the Austrian Hungarian empire was stocked with salt from the Maramures mines".

The main occupations are agriculture as traditional occupation, and commerce. Very many men are gone to work in Russia or in the West: Portugal, Italy and Spain.

Many intellectuals give up their day jobs - engineers, professors, doctors, dentists - and they pick up trading and open prosperous enterprises.

As salaries are very low - especially state paid ones - most Romanians work in constructions especially in Russia. Most often men leave but sometimes their wives accompany them.

With the money they make abroad they start new "biznis'es" but only once they are done building impressive houses - palaces - after the model of the people in Oas, so all Romanian villages resemble the famous town of Certeze near Negresti Oas. The Romanian towns here are the best looking in TransCarpathia and the Romanians here are the most enterprising and hard working in the area and consequently the richest ones. This attitude regarding work quantified in large houses explains the group endogamy which is very well established here.

As expected, the working Romanians get to actually live within their build houses very little as most of the time they are gone abroad to work. Only pupils and elders can be seen on the village streets. The villages suddenly resurrect for the holydays when all those abroad return home to celebrate Christmas and Easter next to their families. Often these periodical visits to the village are also a time to check upon the stage of house construction or to take decisions regarding their completion or alteration. The paradox is that the young ones are left abroad most of the time so they spend very little time - next to nothing - in their houses. Some upgrade them meanwhile so that theirs is better than their neighbors' and so another paradox arises they demolish the roof or modify rooms having never actually inhabited the house for a moment...

Pooper Romanians who did not raise houses like their local Ukraine neighbors live in smaller houses built in the most communist way possible. The older ones all look alike as they have no raised roof. They are cubicle and have no regular roofs as the Soviet authorities only allowed low, metal foil ones.

Beyond their commendable attitude towards work, the households of the Ukraine Romanians are incredible. The older houses have two floors and have flowers and the newer ones are virtual palaces. The newer bigger ones are used as symbols of pride and competition between relatives or neighbors. It is considered that one's wealth is measured in the size of their house - the bigger the better man the 
owner is. As said, Romanians here are considered the richest in Ukraine so that one of the first measures undertaken once the "biznis" is good a new enlargement of the house is performed so that the building is always larger than that of the neighbor's.

The villas of the Romanians are built from the best grade concrete and thick bricks. That is why in front of some houses virtual construction material warehouses are raised; no granite or marble is spared, insulated windows or stainless steel handrails.

The Maramures people here proudly sustain they never sell their houses as they reflect one's wealth and skills but beyond that they don't sell them from the same reason they practice group endogamy: it is a means to keep their ethnical and cultural group tight and to guard the wealth within the group thus ensuring the perpetuation of their own kind. Of course, the presence and continuation of the tradition to build conspicuous houses is yet another identity feature of the Ukraine Romanians, but one that can be read in a mirror as a continuation of an attitude similar to that of the Maramures inhabitants in Romania.

Spiritually, one can observe a divergent attitude: one side the local intellectuals admit the importance of guarding the local cultural heritage as way to keep the Romanian identity - the local folklore groups which demonstrate that, thematic meetings with the local administration or cultural ones (sometimes with Romanian personalities) or founding small private museums - but also an effect to globalization: the adhesion to the neo-protestant groups brought ignorance towards tradition, migration abroad of the working force lead to multiple mutations in the collective mentality.

The pauperization of the villages and the large distances from church along with an aggressive policy by the neo-protestant groups - which sometimes promise money or other types of favors -led to a migration of the population towards these while the ancient religion suffered. The effect was to grow far apart also from the Romanian traditions which are centered to a great extent on a relation to the sacred which is typical to Christianity.

Another alarming finding was that of the disappearing of the religious marriage between Romanian youths who marry after embracing neoProtestantism. Once the position towards this event has been altered all related traditions are considered insignificant - even by the village elders (there are confessions in this matter).

The therapy and magical ritual psychotherapy aspects denote preoccupation which regards tradition. Most of the faiths or scenarios are not effectively performed but they exist within the collective memory especially as collective or individual memories. In fact memory recovery is equivalent to a perpetual contact to tradition. Therapeutical and psychotherapeutical magic territory offer a very wide field of study for guarding the cultural identity of the Ukraine Romanians but also to argument the idea that the collective memory of these Romanians across the country's borders is common to that of the Romanians within the borders and it comes from the same shared beliefs, customs and traditions.

The subjects interviewed on several research campaigns in the Romanian villages on the right Tisa bank revealed common practices to those detected in the Romanian Maramures. We were especially drawn towards the sequences of collective imaginary, magical religion acts and antitherapeutical magic sequences - and by reflex magical therapeutical acts - which integrated perfectly within the wider patterns of Romanian magic as a whole.

The unanimous opinion of those who made a thorough and judicial study of the Romanian land is that the current practices of the therapeutic white magic, mainly the one that is focused on somehow common areas, like the health of the young child or the small ordinary accidents, are known in all the environments of the traditional Romanian community. This opinion is also shared by Martin Segalen who focuses his observations on this "domestic" or "household" aspect of therapeutic magic, because in the French villages many of the mothers could perform therapeutic actions with immediate effect.

Likewise, Jeanne Favret-Saada, approaching the subject of magic in Normandy, she refused totally to believe in a backward and stupid rural world, but on the contrary, she found intelligent countrymen that could perform in causality relationships better than anyone else.

Any folkloric culture has a universal background and, as it has models, it can develop a range of local creations of wide originality, with characters in all the fields, that are able to continue and institutionalize the traditional psychotherapeutic model. The traditional community takes, by direct heritage, a series of archetypal structures, with a reverse in the mentality background, which they can adapt according to subjective and objective factors, to its own history.

Prominent characters of witches are illustrated by Radu Rãutu and Gheorghe Pavelescu in their field observations: among the witches there were ones that were famous and who "could attract rich clients"; "but although the tradition is almighty, and here it is also asserted the law of the individual alternatives, through which the creator of folkloric deeds expresses his personality. It is noted that each witch has a limited number of subjects (of disease etc), of images and magic motifs". They are women with an impressive professional profile and with a reputation that turned them into models, and in some cases they also got to institutionalization, that are dealt with by the anthropologists that studied the 
exotic tribes.

In $\mathrm{Ap}^{\circ} \mathrm{a}$ de Jos, one of the villages with Romanian population from Ukrainian Transcarpatia, on Lenina Street, at no 238, there lives Mãria lui Holdi $^{\circ}$, on her real name Costevici Maria Irjina. As we realized after several field campaigns in the area aunt Mãria is officially known as the most prominent witch in Zacarpatia. Everybody knows Aunt Mãria. There can be found plenty of information about her, within the villages that were under scrutiny and all the subjects in the Romanian villages of Zacarpatia that were interviewed see Aunt Mãria as the most skilled witch in the area (a psychotherapist as we would name her).

Aunt Mary is a woman that you can hardly tell the age. She is short, wise and blue-eyed. You can notice she is not a woman tired by the field work and that she spends a lot of time in the house, praying and performing therapeutic incantations. Aunt Mãrie combines medical knowledge, which she received from an old physician in the area, that she worked with in her youth, with some bioenergy characteristics that she developed, probably by using them repeatedly. Everything is overlapped on a background of magic features that is used to operate the traditional scenario of the healing: disease incantations, massages, ritual incantations, specific tools, and everything being done according to the popular magic principles.

From the point of view of the field ethnographer, we can also notice that the magic activity of the Romanian witches from Ukraine belong to the magic-ritual pattern that is used throughout the areas that are inhabited by Romanians.

For the traditional Romanian society, wedding is both a personal and family event and also a social communitary one.

Just as within the Romanian Maramures villages, the Maramures villages across Tisa see wedding as a precisely staged script, while covering a ritual taken from the cultural background - with all its identity features.

Performing the traditional wedding means to overlap a row of ritual actions the significance of which is not very clear anymore to the group but which becomes activated on well-established customs.

We believe that the strongest and most dramatic mutation in the nuptial scenario in the Romanian villages across Tisa is provoked by the great success of the neo-protestant proselytes: an impressive number of Catholic Orthodox Romanians in these villages have abandoned their religion and crossed to Jehovah's Witnesses. This imposed a few major alterations to the nuptial economy: firstly the religious ritual is no longer performed in church. None of the young Jehovah's Witnesses go through the religious marriage but instead they only receive a civil marriage. Then the Witnesses do not accept dance and drinking so that weddings are no longer as they used to be within the complex Romanian wedding pattern - and on this occasion all traditional customs related to marriage have been lost.

A field research performed within the past years in Ukraine emphasizes the large degree of tradition dissolution especially visible in the alteration of one's religion. In fact, this is where one can see most modifications due to the abnormal environment and pressure by the dominant community is that of the two main institutions within the village life: church and school. Confessional we observe that most Romanians on the right Tisa bank have left their ancestors' Orthodox or Catholic Church and go now to the House of the Kingdom - the space of the Jehovah's Witnesses who are present in an impressively large number in the right Tisa villages.

The explanation to our questions generated by the observations towards changing one's faith was a simple and pragmatic one concerning commodity and efficiency even though behind these facts initiatives of religious proselytism are hidden. The Romanian Orthodox go to the Houses of Kingdom as they feel the urge to go to church somewhere and there is none in the village which is Orthodox or it is too far away from the center of the village. All interviewed subjects believe that if there were Orthodox or Catholic churches built in the village more people would go to church but as they do not exist, must of them go to Jehovah's Witnesses.

The Romanian traditions concerning the major moments in the traditional calendar be it Christian or folkloric - with celebrations which were instituted by tradition and which were held on the right Tisa bank until the religious conversion of the Christians took place are no longer held. It is known that "the religious services of the Jehovah Witnesses are based upon learning the way of Jehovah and how to propagate it. Rituals concerning christening, marriage and funeral are very minimalistic. (...) The Organization forbids their members to participate to annual events like Easter, Christmas, birthdays or national celebrations".

A partial conclusion to the field research in the last few years denotes that the identity of the Romanian community at the Ukraine Maramures border is built on several levels - sometimes with local innovations and sometimes with changes of orientation due to the pressure of cultural assimilation. These always happen related to the actions, behavior and mentality models of the Maramures inhabitants in Romania as proven in many of the confessions of those interviewed who most of the times begin their story with a somewhat established formula: "with us Romanians, the same as with you..." and only afterwards they mention the differences.

In fact, Mihai Dancus, a knowledgeable researcher of the right Tisa villages history outlines in his works by involving certain examples of immate- 
rial heritage from the area "the specificity of these villages but also the obvious similarities which emphasize the unity of the popular Romanian Maramures culture as a whole".

\section{References:}

${ }^{1 .}$ Adrian Fochi, Paralele folclorice: coordonatele culturii carpatice, Editura Minerva, Bucureşti, 1984, p. 12.

2. Adrian Fochi, op. cit., p. 19.

${ }^{3 .}$ Ion Popescu, Cuvânt inainte: să se ştie cine-am fost..., în Ion Popescu, Constantin Ungureanu, Românii din Ucraina între trecut şi viitor, Editura Primus, Oradea, 2009, p. 2.

4. Michailo Lucikai, Pagini de istorie, Editura Mustang, București, 2004, p. 283.

${ }^{5}$ Alexandru Filipașcu, Ucrainienii din Maramures, Sibiu, 1945, în Cristina Țineghe, "Dezmembrarea Maramureșului istoric: decizii politice, reacții și consemnări în mărturii contemporane (1919 - 1923)", București, Editura Centru de Stuidii pentru Resurse Românești, 2009, p. 184.

${ }^{6}$ Mihai Dăncuș, Zona etnografică Maramureș, Editura Sport - Turism, București, 1986, p. 36.

${ }^{7}$ Mihai Dăncuș, op. cit., p. 46 - 56 .

${ }^{8 .}$ Mihai Dăncuș, op. cit., p. 67.

${ }^{9}$ Martine Segalen, Mari et femme dans la société paysanne, Edition P.U.F., Paris, 1980.

10. Jeanne Favret Saada, Les mots, la mort et les sorts. La sorcellerie dans la Bocage, Edition P.U.F., Paris, 1977, p. 16.

11. Vasile Crețu, Ethosul folcloric - sistem deschis, Editura Amarcord, Timișoara, 1980, p. 48.

12. Răutu, Radu. Antologia descântecelor populare româneşti, Editura Grai şi suflet - Cultura naţională, Bucureşti, 1998, p. XV.

13. Radu Petre Mureșan, Atitudinea Bisericilor Tradiționale Europene fața de prozelitismul advent. Impactul in societatea contemporană, Editura Universității din București, București, 2008, p. 96 97.

14. Mihai Dăncuş, Maramureşul din dreapta Tisei vestigii ale identităţii, în "Caietele ASER", nr 3/2007, Oradea, 2007, p. 348

Бургеле Камелія. Домащня антропологія румунських сіл на правобережжі Тиси (Закарпаття, Україна) У статті поданий етнографічний опис громад румунських сіл на правобережжі Тиси (регіон Марамуреш) протягом останніх років. У роботі представлені особливості етнічної історії східної частини українського Закарпаття. Важливо, що в географічному плані, 2/3 території історичної Мараморощини належать Україні, 1/3 - Румунії. Румуномовне населення тут завжди ставилося до свого походження незалежно від контексту глобалізації. Ідентичність румунської громади в українській частині Марамурешу побудована на кількох рівнях - частково на основі місцевих особливостей і традицій, а частково підпорядкована змінам та орієнтації на глобалізацію в зв'язку з культурною асиміляцією. Ці рівні пов'язані
3 особливостями поведінки та менталітету жителів Марамурешу.

Ця робота $є$ частиною більш комплексного дослідження культурної самобутності румунського населення Північної Мараморощини, їхньої соціальнокультурної динаміки в багатоетнічному середовищі в межах проекту Румунської академії наук "Пропагування культурної самобутності в рамках глобальних процесів", за підтримки Європейського соціального фонду "POSDRU" (2007 - 2013 рр.).

Частина румуномовного населення Марамурешу самоідентифікують себе румунами, вони мають змогу реалізувати свої національні потреби: право на розвиток своєї культури, мови, конфесійних потреб; візити до своїх побратимів у румунській частині Марамурешу; культурний обмін; існування румуномовних шкіл, власних музеїв; друк періодичних видань румунською мовою тощо. Опитування представників багатьох конфесій довели, що в більшості випадків мешканці починають свою історію 3 усталеної формули: "3 нами, румунами, так само, як із вами ... " і тільки після цього вони згадують про відмінності.

Ключові слова: історична Марамуреш, румунські села Закарпаття, культура Карпат, етнічна і культурна ідентичність, ідентичність кордону.

Бургеле Камелія - доктор наук, старший консультант, магістр румунської культури і циввілізації, докторант в галузі антропології та фольклору Румунської академії, член Асоиіачії етнології Румуніі (ASER), автор семи книг про антропологію здоров'я $i$ (Селаж, Румунія)та етнографію.

Burghele Camelia - doctor of science, senior specialty consultant, Master in Romanian Culture and Civilisation, postdoctoral studies on anthropology and folklore at the Romanian Academy, member of the Ethnology Association of Romania (ASER), author of seven books on health anthopology and Meses area (Salaj County, Romania) ethnography.

Received 12-11-2015

Advance Acces Publischer: December 2015

(C) C. Burghele, 2015 